\title{
The effectiveness of a blended learning program on developing Palestinian tenth graders' English writing skills
}

\author{
Awad Soliman Keshta ${ }^{1}$, Ismail Ibrahim Harb ${ }^{2}$ \\ ${ }^{1}$ College of Education, the Islamic University of Gaza (IUG), Palestine \\ ${ }^{2}$ Ministry of Education, Gaza, Palestine
}

Email address:

Dr.awadk@yahoo.com(A. S. Keshta), ismail_harb2005@yahoo.com(I. I. Harb)

\section{To cite this article:}

Awad Soliman Keshta, Ismail Ibrahim Harb. The Effectiveness of a Blended Learning Program on Developing Palestinian Tenth Graders' English Writing Skills. Education Journal. Vol. 2, No. 6, 2013, pp. 208-221. doi: 10.11648/j.edu.20130206.12

\begin{abstract}
This study aimed at investigating the effectiveness of using a blended learning program on developing Palestinian tenth graders' English writing skills. To achieve the study aims, the researchers designed a writing achievement test consisting of (40) items. The sample study consisted of (40) students from Shohadaa' Rafah Basic School in Rafah Directorate of Education 2012-2013. The blended learning program was used in teaching the experimental group (20) students, while the traditional method was used with the control one (20) students in the second term of the school year (2012-2013). The experiment lasted for eight weeks. The study findings revealed that there were significant differences at ( $\alpha$ $\leq 0.05)$ in the mean scores of the test in favor of the experimental group. The findings also pointed out that there were statistically significant differences at $(\alpha \leq 0.05)$ in the participants' achievement level before and after implementing the blended program in favor of the post-application. This was attributed to the blended learning program in teaching writing. In the light of the study results, the researcher recommended that education stakeholders should adopt the blend in teaching English, hold educational courses and workshops for teachers in employing blended learning to enrich the teaching learning process, create effective learning environment that enhances self- learning and develops students' achievement level.
\end{abstract}

Keywords: Blended Learning, Effectiveness, Writing Skills

\section{Introduction}

Writing is necessary in everyday life, in business, in creativity, and in scholarly pursuits. Additionally, Carroll (1990: 1) asserts that writing is the most important invention in human history because it provides relatively permanent record of information, opinions, beliefs, feelings, arguments, explanation and theories. It allows us to share our communication not only with our contemporaries, but also with future generations. It permits people from the near and far distant past to speak to us. It is vital for teachers to employ effective methods of teaching that enhance students' ability to communicate ideas and feelings via writing. Online learning provides major benefits to both students and teachers. The benefits include convenience, time and geographic flexibility (Bates, 2000). Delacey, and Leonard (2002), Rossett, Douglis, and Frazee (2003) have proved the existence of several problems facing e-learning: e-learning programs cost a lot; students who learned electronically are less efficient in expressing their ideas.
Blended learning is natural evolution of e-learning towards a complete program of various multimedia applied in an ideal way to solve problems, taking into account the individual differences and achieving a distinguished teaching. It is considered one of the modern trends based upon employing information technology in designing new learning situations which increase active learning and learner-centered strategies. Blended learning combines the advantages of face-to-face and e-learning to satisfy individual differences (Bersin and Associate, 2003). Bonk and Graham (2006: $3-5$ ) points out that blended learning is not just about using technology because it is available; blended learning is about finding better ways of supporting students in achieving the learning objectives and providing them with the best possible learning and teaching experiences, as well as supporting teachers in their role (including the management and administration of courses).

The above mentioned viewpoints and discussions support developing teaching approach to develop writing skills and highlight the importance of blending various multi-media 
with face-to-face.

\subsection{Statement of the Problem}

The researchers have observed students' low achievement in writing skills in achievement tests. Although our students have good access to modern technologies, they do not make use of them in their learning in general and English learning in particular. Hence, the researchers believe in the importance of using blended learning program in developing students' writing, where the use of various multi-media could help students employ writing skills into daily writing tasks such as emails to a friend, posting or sharing ideas through texts or short paragraphs which may assist students become more effective communicators through writing

\subsection{Research Questions}

In the light of the study problem, the following questions emerged:

1. Are there differences in the achievement level in writing skills in the post test between the students of the experimental group (blended learning) and their counterparts of the control group?

2. Are there differences in the achievement level in writing skills between the students of the experimental group (blended learning) in the pre-post test?

\subsection{Purpose of the Study}

The current study aimed at investigating the effectiveness of the blended learning program on developing and retention of Palestinian tenth graders' English writing skills.

\section{Literature Review}

\subsection{Writing}

According to Chastain (1988: 244) "Writing is a basic communication skill and a unique asset in the process of learning a second language" while Sokolik, (2003) describes writing as the mental work, which involves inventing ideas, thinking about how to express them, and organizing them into sentences and paragraphs that will be clear to readers. In describing writing, Olshtain, (2001), and Reid, (2002) point out that it is the process of documenting thoughts and experiences. It is viewed as a communicative social activity through which one can communicate a variety of messages to a close or distant, known or unknown reader(s).

\subsubsection{The Nature of Writing}

Writing is not merely putting down word after word to form a sentence or writing one sentence beside the other to form a paragraph. The difficulty lies in generating and organizing ideas as well as in translating these ideas in writing in English Language (EFL Writing) into coherent, accurate, informative and readable text (Richards and Renandya, 2005). Writing is not always spoken words put onto paper. Richards (2003) explains the difference between written language and spoken discourse saying that written language employs different syntax and vocabulary. It uses complex rather than simple clauses, a greater variety of clause types, more specific vocabulary, more complex verb phrases and tenses and more devices. According to Dixon, (1986), Haring, (1994) and Johnstone et al., (2002) writing is not limited to using orthographic symbols, according to a certain purpose. It also requires selecting and organizing experience according to a particular purpose.

\subsubsection{Teaching Writing}

Harmer (2001: 79-84) explains four reasons for teaching writing to students of English as a foreign language. They are reinforcement, language development, learning style and writing as a skill:1- Reinforcement: some students acquire languages in an oral /aural way; others get benefit from seeing the language written down. The visual demonstration of language construction is invaluable for both understanding and memory". It is useful for students to write the new language shortly after studying it. 2- Language development: the process of writing is different from the process of speaking; the former helps us to learn as we go along. "The mental activity of constructing proper written texts is part of the ongoing learning experiences". 3Learning style: some students are quick at acquiring language just by looking and listening. Others may take longer time to spend in producing language in a slower way, thus making writing appropriate for those learners. 4Writing as a skill: the most essential reason for teaching writing is that it is a basic language skill like speaking, listening and reading. Students need to know how to write letters, compositions, essays, reports, and how to use writing's conventions.

\subsubsection{The Principles of Teaching Writing}

Tang (2006) applies some principles for developing writing skills in teaching writing and how they can be applied in a Chinese ESL classroom: 1-Raise students awareness: Students should be helped to see the role of writing in language learning. 2- Students have ideas: Students have not only the exposition of ideas, but also the working out of ideas". It is teachers 'responsibility to help students analyze their own ideas through teaching. 3- Read to write: Writing does not exist alone. Before a leaner starts to write, he/she needs to read so as to learn the language and get familiar with certain patterns or rhetorical structures. 4Teach process writing: Process writing is characterized by the awareness of the writer of the writing process and the intervention of a teacher or peers at any time during the process of writing to improve writing skills instead of fixing mistakes. This approach aims at enabling students to share information, make personal choices about reading and writing, take the responsibility of their own learning task, take writing as process, and develop cooperation. 5- Create a learner-centered classroom in active communication: Basically, writing is a verbal communication. The view that writing is a verbal communication finds the strongest support in Bakhtin`s dialogic theory of language. It implies the interactive nature of writing. 


\subsubsection{Writing Skills}

Palmer (1986) analyzes the skills attached to writing under five headings:

A) Graphical or visual skills:

1. Writing graphemes (letters of the alphabet).

2. Spelling.

3. Punctuation and capitalization.

4. Format (such as the layout of a letter or a shopping list).

B) Grammatical skills: These refer to the pupils' ability to use a variety of sentence patterns and constructions successfully.

C) Expressive or stylistic skills: They include the pupils' ability to express precise meanings through various styles.

D) Rhetorical skills: They refer to the pupils' ability to use linguistic cohesive devices. The elements of rhetoric were treated under five headings: invention, arrangement, diction, memory, and delivery.

E) Organizational skills: These are skills concerned with organizing pieces of information into paragraphs and texts. This involves the sequencing of ideas and the avoidance of irrelevant information.

\subsubsection{Writing as a Process}

Min and Li (2007: 42) emphasize that "Process writing is learning how to write by writing." This current emphasis in writing instruction focuses on the process of creating writing rather than the end product. The basic premise of process writing is that all learners can write and the focus here is on creating quality content and learning the genres of writing. Johnstone et al. (2002) assure that writing is an interactive process involving the following elements:

1. The writer's long-term memory: This includes knowledge of topic, audience and writing plans developed through previous experience.

2. The task environment: It involves the specific rhetorical problem the writer encounters (e.g. topic and audience).

3. The writing processes: These involve planning, translating, reviewing and monitoring sub-processes. Interaction between these elements is important for developing writing skills. For example, writers whose long-term memory is updated in a rich meaningful task environment are likely to develop better writing skills. Lindsay and Knight (2006: 94-95) break down the writing process into three stages:

1- Preparation: Think about the reader, consider why we are writing, think about the content, and decide the appropriate layout and style.

2- Drafting: Put our ideas together in a draft form. This is probably all we need for things like shopping lists and memos. Gebhardt and Rodrigues (1989: 45) indicate that drafting and redrafting can be done several times during writing process.

3-Editing and Rewriting: Write several times so that the text is coherent and clear.

The researchers believe that EFL learner need more practice in order to focus on these stages and thus develop their writing skill.

\subsubsection{Mechanics of Writing}

Mechanics of writing is a writing sub-skill. Norman et al. (2005) define it as "the sub-skill that includes such things as punctuation, spelling, abbreviations, acronyms ...etc ". Similarly, Sun (2003) simply states that mechanics of writing specifies the established conventions for words that one uses in his / her documentation. These conventions include capitalization, contractions, gerunds, participles, numbers, numerals, pronouns, technical abbreviations, acronyms, units of measurement and punctuation marks.

\subsubsection{Punctuation}

Angelillo, (2002) points out that punctuation marks are one of the components of writing mechanics. These marks are divided into internal marks - referring to the punctuation marks within the sentence - and end marks - which are used at the end of a sentence or a question. Another classification of punctuation marks by Sun, (2003) divides them into marks within the word like apostrophes and hyphens, marks between words and end marks. Incorrect punctuation may create document noise and confusion. Knowing where to punctuate and why contributes to accurate editing.

\subsubsection{Capitalization}

King (2003) regards capital letters as a form of punctuation in that they help guide the eye and mind through a text. He adds that the common usages of capital letters to start sentences and surnames are clear enough; however, a good deal of mystery surrounds the use of capitals in some other areas of writing.

\subsubsection{Coherence and Cohesion}

Coherence is very essential in enabling the reader to follow the flow of ideas and the intended meaning of the writer. Richards, (1990) supports the effectiveness of coherence as an important quality of effective writing. Gebhardt \& Rodrigues (1989: 81-83) point out the importance of coherence in making ideas stick together where each sentence should relate to the proceeding and following sentences. They mention four tools that enhance coherence:

1. Repetition of words, ideas, phrases ...etc.

2. Synonyms.

3. Pronoun reference.

4. Transitional markers

Many researchers agree that cohesion, on the macro level is related to linking ideas whereas on the micro level, it is concerned with connecting sentences and phrases. Cohesion refers to the explicit linguistic devices that link the sentences in a text. These cohesive devices include reference, substitution, ellipsis, conjunction and lexical cohesion (Halliday \& Hasan, 1985), and since they are manifested at the surface level of a text, cohesion should be relatively straightforward to identify.

\subsection{Blended Learning}

The North American Council for Online Learning (NACOL, 2008: 5-10) defines the blended learning setting 
as the combination of online delivery of content with the best features of classroom interaction and live instruction to personalize learning, allow thoughtful reflection, and differentiate instruction from student to student across a diverse group of learners.

\subsubsection{Blended Learning Environment}

Blended learning is the natural progress of e-learning towards a complete program of various multi-media and applying it in an ideal way to solve problems. Blended learning, as mentioned above, blends both e-learning and face-to-face learning. Figure (1) depicts the rapid growth of distributed learning environments and its convergence with face-to-face learning environments. The intersection of the two archetypes depicts where blended learning systems are emerging (Graham, 2004: 6)

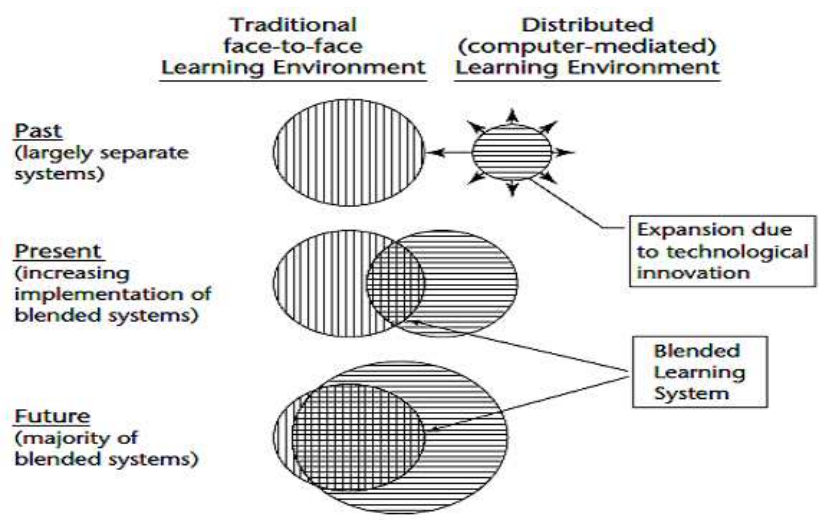

Figure 1. Progressive convergence of traditional face-to-face and distributed environments allowing development of blended learning systems

Blended learning environment which is regarded as a type of distance education integrates the advantages of distance education with the effective aspects of traditional education, such as face-to-face interaction. In contrast to classical learning environment which poses restrictions on place and time, e-learning provides an environment where the learners can study regardless of time and place restrictions. The factors such as learners' individual differences, personal characteristics and learning styles have significant impacts on the learning environment. For instance, the learners who have difficulty in establishing communication in the classroom environment find it easier to communicate in the electronic environment. It is obvious that the weaknesses and strengths of online environment and the weaknesses and strengths of face-to-face education integrate in blended learning (Finn \& Bucceri, 2004). Assuming such an environment results in:

1. Students' having more control over their learning (Hooper, 1992, Saunders and Klemming, 2003);
2. Increasing social competencies.
3. Improving student morale and overall satisfaction .
4. Enhancing information skills acquisition and student achievement
5. Respecting differences in learning style and pace

(Kendall, 2001) and;

6. Fostering communication and closeness among students and tutors (Joliffe, Ritter, and Stevens, 2001 as cited in Wood, 2009).

\subsubsection{Characteristics of Blended Learning}

Huang, Zhou and Wang (2006) assume that blended learning has three characteristics. The first is flexibility of providing learning resources. The second is support of learning diversity. As learners are diverse in terms of learning styles, learning proficiency, as well as learning ability, blended learning can come to the rescue by making it possible for individualized learning and self-regulated learning to happen. The third is enrichment of e-learning experience. From the faculty's perspective, blended learning can enable them to improve their existing teaching practices.

According to Al Fiky (2011: 23-24), blended learning redesigns the educational model with these characteristics:

1. Moving form lectures to student centered learning.

2. Maximizing teacher-student, student-student, student-content, student-outside resources interaction.

3. Integrated evaluation techniques for teachers and students.

4. Broaden the spaces and opportunities available for learning. (Bath and Bourke, 2010: 1);

5. Support course management activities (e.g., communication, assessment submission, marking and feedback).

6. Support the provision of information and resources to students.

\subsubsection{Levels of Blended Learning}

As pointed out by Graham (2004: 10-12), blended learning can occur at different levels, such as the student activity level, course level, program level, and institutional level. Students at different levels of their university studies need a teacher to support their learning activities, but in all levels the teacher should soon draw back and emphasize student's self-regulation in learning. Al Fiky (2011: 42-45) classified it according to its nature, quality and the degree of blend to four categories:

1. Component level: This depends on the combination between several information transfer media and the learning content to form a whole which consists of several separated components that differ according to the learners' nature and available traditional or electronic learning resources.

2. Integrated level: It is integration among different elements of the electronic learning based upon the internet. Each component supports other components and evaluation is one of these integrated components to measure the learners' ability to perform the assigned learning tasks.

3. Collaborative level: It is based on blend between the teacher (as a guide) and the co-operative learning groups in the traditional classroom or the collaborative learning groups on the internet. 
4. Expansive level: The blend between traditional classroom learning and offline electronic learning resources (email, electronic documents and books, programs)

\subsubsection{Elements and Design of Blended Learning}

Blended learning designs differ according to the elements that are blended, the percentage of these elements in the course credit, and the objectives of the courses.

\subsubsection{Models of Blended Learning}

There are several models like Khan's Octagonal Framework, Huang, Al-Jazar ...etc. Al-Jazar model consists of five phases; study and analysis, design, production, evaluation and usage as clarified in Figure (2). (Al-Jazar, 2002):

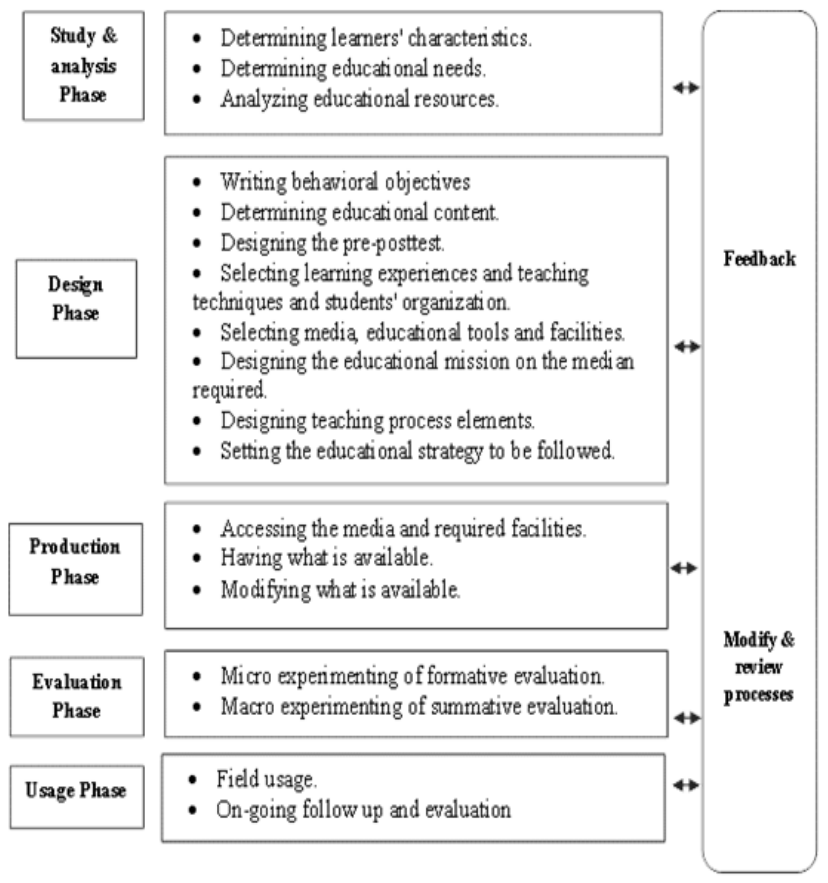

Figure 2. Al-Jazar Model: Designing and Producing Multimedia Interactive Programs

The researchers adopted Al-Jazar model for the blended learning program following all the five phases; analyzing learners', educational needs and resources, program design, producing the required media and facilities, evaluating the program and finally implementing the program with on-going assessment and evaluation.

\section{Reasons for Choosing Al-Jazar Model}

1. The model has a lot of educational applications in the Arab World, which proves its reliability.

2. It follows the scientific approach of thinking.

3. It has logical sequence from analyzing learners' characteristics as well as needs and tries to find appropriate solutions that satisfy them.

4. Sub-stages are organized systematically.

5. It covers all the teaching learning events.

6. Its suitability to novice designers.

\subsubsection{Factors Influencing the Application of Blended Learning}

A number of factors affect the use of blended learning in language courses:

1. Teachers' and learners' attitudes; positive, negative or neutral.

2. Learner's level may influence the technology to be used and how it is used.

3. The training the teacher has got about employing technology inside the class.

4. Teachers' and learners' access to technology incorporating it in the courses.

5. Cost of supported materials. (Sharma and Barrett, 2007: 12-13)

\subsubsection{Blended Learning Design Process}

The selection, organization and primary presentation of course content, as well as the design and development of learning activities and assessment, is a pivotal responsibility for the instructor (Billigmeier, 2011). Bath and Bourke, (2010) describe a five phase design for blended learning as a systematic approach, starting with:

1. Planning for integrating blended learning into your course, followed by;

2. Designing and developing blended learning elements;

3. Implementing the blended learning design;

4. Reviewing (evaluating) the effectiveness of your blended learning design, and;

5. Planning for the next delivery of your course then involves improving the blended learning experience for both staff and students.

\subsubsection{Advantages of Blended Learning}

Osguthorpe and Graham (2003) identify six reasons why one might choose to design or use a blended learning system: (1) pedagogical richness, (2) access to knowledge, (3) social interaction, (4) personal agency, (5) cost effectiveness, and (6) ease of revision. Graham and Robinson (2007) add three other reasons that encourage people to select the blended learning approach i.e. improved pedagogy, increased access, and flexibility.

Al Fiky (2011: 24-26) summarizes the benefits of blended leaning as follows:

1. Increasing students' interaction and participation.

2. Developing students' learning and performance.

3. Affecting teachers' approaches of other subjects.

4. Developing independent learners, a source of instant feedback, time saving and motivation to learners (Sharma and Barrett, 2007: 10-12);

5. Increasing student learning outcomes and reduce instructional delivery costs. (Dziuban, Hartman and Moskal, 2004) and;

6. Maximizing classroom space and/or reduce the number of overcrowded classrooms. Gould (2003: $55)$;

7. Allowing institutions to offer more classes at peak demand times of the day, thus maximizing the scant resources by increasing flexibility in scheduling. 
8. Reducing paper and photocopying costs. In hybrid courses, all course documents, including syllabi, lecture notes, assignment sheets and other hard copy handouts, are easily accessible to the students on the course web site.

A lot of studies confirmed those advantages of blended learning. For example, Oblender's (2002) study revealed that blended learning increased the percentage of students' punctuality in the daily attendance to $99 \%$ from the students in general. While a study conducted by Gamble (2005) proved that blended learning led to expanding and improving students' learning experiences, and the results of Milheim's study (2006) revealed some of the advantages of blended learning like; Immediate feedback for students, face-to-face interaction with the teacher during learning, and the flexibility of handling different content subjects according to the available circumstances.

\subsubsection{Challenges Facing Blended Learning}

The application of blended learning revealed some of the difficulties and challenges which might affect the quality of teaching and learning and hinders the expansion of using it in a wide range in the teaching. Hofmann (2011) describes a variety of technical, organizational, and design challenges facing blended learning:

1. Ensuring participants' ability to use technology successfully.

2. Overcoming the idea that blended is not as effective as traditional teaching.

3. Managing and monitoring participant progress.

4. Matching the best delivery medium to the performance objective.

5. Keeping online offerings interactive rather than just "talking at" participants.

6. Some adults experience some computer-related phobia (Saade and Kira, 2009) and;

7. Frustration, confusion, anger, anxiety and similar emotional states which may be associated with the interaction can adversely affect productivity, learning, social relationships and overall well-being.

\section{Previous Studies}

\section{Al-Masry (2012)}

This study investigated the effectiveness of using electronic blended learning in teaching a unit in English course at the cognitive levels (recognition , comprehension, and application) by second year secondary female students in Makkah. The quasi-experimental approach was used. The study population was all (156) female students in the second secondary school in Makkah. The study sample was (56) students, divided into two groups: an experimental group of (31) students, and a control of (25) students. An achievement test prepared by the researcher was used to collect data. The results concluded there were statistically significant differences at (0.05) level between the average test scores of the group of students who learned by using the electronic blended learning, and the control group of students who learned by using the traditional method in post-application of the achievement test at the " recognition ", "comprehension" and "application" level in favor of the experimental group.

\section{Sayed (2012)}

This study investigated the effect of the electronic portfolio on developing the English language writing skills for second grade preparatory school students. The sample was (60 students) selected from Nader El-Riyadh Preparatory School. They were divided into two groups: control (30 students) and experimental (30 students). The students of the experimental group practiced writing on a website under the teacher's guidance and feedback. A post writing test was administered to collect data. The results showed there was a statistically significant difference between the mean scores of the experimental group and the control group at the $\left(\begin{array}{ll}0.0 & 1\end{array}\right)$ level in favor of the experimental group's mean score. It was concluded that the electronic portfolio had a large effect on the writing skills of second year preparatory school students.

\section{Kocoglu, Ozek and Kesli (2011)}

This study examined the effectiveness of a blended learning approach for a teacher training program designed for in-service English language teachers, compared with a face-to-face Program in English Language teaching. The research involved 39 in-service English language teachers, with 12 studying in a blended course (i.e., they received face-to-face instruction in the classroom and used web-based materials) and 27 in a traditional classroom. The study followed a quasi-experimental study with a non-equivalent groups design. To collect data from the study sample, the researchers used Teaching Knowledge Test (TKT), final course grades (assignments, exams, projects and quizzes), and a feedback questionnaire. Results indicated that there was no difference in content knowledge acquisition between teachers receiving blended instruction and teachers receiving face-to-face instruction.

\section{Shih (2011)}

This study investigated the effect of integrating "Facebook" and peer assessment with college English writing class instruction through a blended teaching approach. The subjects were 23 first-year students majoring in English at a technological university in Taiwan participating in an 18 week English writing class. Both quantitative and qualitative approaches were employed in the study. Research instruments included pre-test and post-test of English writing skills, a self-developed survey questionnaire, and in-depth student interviews. The findings suggested that incorporating peer assessment using "Face book" in learning English writing can be interesting and effective for college-level English writing classes. Students can improve their English writing skills and knowledge not 
only from the in-class instruction but also from cooperative learning. In addition, this "Face book" integrated instruction can significantly enhance students' interest and motivation.

\section{Kaoud (2007)}

This study examined the effectiveness of internet blended discussion group on developing some composition writing skills of first year secondary school students, namely language use skill (structure) and the writing mechanics (punctuation, capitalization, spelling and paragraphing). For this purpose (60) EFL students enrolled in the old secondary school for girls in Kafr El-Sheikh city were randomly selected and randomly assigned to two groups; one control and the other experimental. The experimental group was taught using the internet discussion, whereas the control group adopted the traditional method to the teaching of composition. A composition writing skills pre-post test was used to collect data. Results revealed there were statistically significant differences at (0.05) level between the average test scores of the group of students who learned by using the internet blended discussion, and the control group of students who learned by using the traditional method in favor of the experimental group.

\section{Al-Jarf (2004)}

This study tried to find out whether there were significant differences in achievement between English-as-a-foreign-language (EFL) freshman students exposed to traditional in-class writing instruction depending on the textbook only, and those exposed to a combination of traditional in-class instruction and Web-based instruction in writing. The study sample consisted of 113 EFL freshman students in first semester of translation program at College of Language and Translation, King Saud University in Saudi Arabia. All students were pretested before instruction and studied the same writing textbook for 12 weeks. In addition, the experimental group received online instruction in which they posted their own threads, short paragraphs, stories, or poems on a discussion board. They located information related to themes covered in the book from Internet sites such as "Yahoo! Movies" and "WebMD." They word processed their paragraphs and checked their own spelling using Microsoft Word. At the end of the treatment, both groups were post tested. Results showed that the experimental group scored significantly higher than the control group. Web-based instruction proved to be an important factor in enhancing the writing quality of unskilled, low ability EFL students and resulted in a significant improvement in their post-test scores.

It is obvious that nearly all the studies which were conducted in various environments have examined the effectiveness of blended learning in the teaching learning process inside or outside the classroom. Nearly all the studies have displayed blended learning as significant method in sustaining students' achievement, attitudes and perceptions in various subjects where teachers employed it as an alternative for completely face-to-face or on-line learning.

\section{Methodology}

This study aimed at investigating the effectiveness of using a blended learning program on developing and retention of Palestinian tenth graders' English writing skills.

\subsection{Research Design}

The researchers adopted the quasi experimental approach. Two groups were assigned as the participants of the study; the experimental group, and the control group. The research includes three variables; the first variable is blended learning program, the second variable is writing skills, the third variable is writing skills retention. The experimental group was taught writing via blended learning, while the control group was taught via the traditional method. The experiment lasted for eight weeks. Both groups were taught by the same teacher.

\subsubsection{Population of the Study}

The population of the study consists of all tenth graders at the governmental schools in the Rafah Directorate enrolled in the second semester of the school year (2012-2013) who count ( 1774) according to Ministry of Education records.

\subsubsection{Sample of the Study}

The sample of the study consisted of (40) students distributed into two groups; one experimental group consists of (20) students and one control group includes (20) students The sample of the study was randomly chosen and distributed from the tenth grade classes in Shohada' Rafah Basic School.

Table (1). The distribution of the sample according to the groups

\begin{tabular}{llll}
\hline Group & Experimental & Control & Total \\
\hline No. of sample & 20 & 20 & 40 \\
\hline
\end{tabular}

Both groups were all in grade ten aged nearly 15 . They were chosen from the same school. They were similar in their general achievement in accordance with the statistical treatment of their results in the first term of the school year (2012-2013). In this year, all classes were similar in their achievement as they were distributed according to their achievement in equivalent classes. A pre-test was used to check the similarity of achievement between the two groups.

\subsubsection{The Variables of the Study}

The study included the following variables:

1. The independent variable represented in the blended learning program

2. The dependent variable represented in the tenth graders' English writing skills and retention. 


\section{Instrumentation}

The researchers used the following instruments to achieve the aims of the study:

1- Achievement writing test (Pre \& post)

2- The blended program

\subsection{Writing Test}

The achievement test was prepared by the researchers to measure the students' achievement in writing. It was used as a pre test applied before the experiment, as a post test after the experiment.

\subsubsection{The General Aim of the Test}

The test aimed at measuring the effect of the blended learning program on the subjects' writing skills in English mainly (Form, Coherence and Cohesion). It was designed according to the content analysis, the objectives of each level and the percentage weight for each domain according to Bloom's taxonomy and the table of specifications.

\subsubsection{The Pilot Study}

To examine the appropriateness of the test items, the test reliability, the required time for application, as well as difficulty and discrimination coefficients, the test was administered to a random pilot sample of (15) students from Shohada' Rafah Basic School. Test time, while applying it on the pilot study, was computed according to the following equation:

\section{The time taken by all the students} Students' number

The time of test was (60) minutes. The clarity of the questions was checked. The misleading items were also modified. The researchers found that students are suffering from low achievement in English writing skills.

\subsubsection{The Validity of the Test}

Al Agha (1996: 118) states that a valid test is the test that measures what it is designed to measure. The study used the referee validity and the internal consistency validity .

\subsubsection{The Referee Validity}

The test was introduced to a jury of specialists in the English language and methodology in Gaza universities, Ministry of Education and supervisors and experienced teachers in the governmental schools. The items of the test were modified according to their recommendations.

\subsubsection{The Internal Consistency Validity}

Al Agha (1996: 121) asserts that the internal consistency validity indicates the correlation of the score of each item with the total average of the test. It also indicates the correlation of the average of each skill with the total average. This validity was calculated by using Pearson Formula.
Table (2). Correlation coefficient of every item of the test with the total score

\begin{tabular}{llllll}
\hline No. & $\begin{array}{l}\text { Pearson } \\
\text { correlation }\end{array}$ & Sig. level & No. & $\begin{array}{l}\text { Pearson } \\
\text { correlation }\end{array}$ & Sig. level \\
\hline $\mathbf{1}$ & 0.560 & 0.015 & $\mathbf{2 1}$ & 0.505 & 0.027 \\
$\mathbf{2}$ & 0.691 & 0.002 & $\mathbf{2 2}$ & 0.603 & 0.009 \\
$\mathbf{3}$ & 0.477 & 0.036 & $\mathbf{2 3}$ & 0.587 & 0.011 \\
$\mathbf{4}$ & 0.630 & 0.006 & $\mathbf{2 4}$ & 0.456 & 0.044 \\
$\mathbf{5}$ & 0.463 & 0.041 & $\mathbf{2 5}$ & 0.642 & 0.005 \\
$\mathbf{6}$ & 0.648 & 0.004 & $\mathbf{2 6}$ & 0.607 & 0.008 \\
$\mathbf{7}$ & 0.530 & 0.021 & $\mathbf{2 7}$ & 0.489 & 0.032 \\
$\mathbf{8}$ & 0.671 & 0.003 & $\mathbf{2 8}$ & 0.750 & 0.001 \\
$\mathbf{9}$ & 0.556 & 0.016 & $\mathbf{2 9}$ & 0.607 & 0.008 \\
$\mathbf{1 0}$ & 0.691 & 0.002 & $\mathbf{3 0}$ & 0.677 & 0.003 \\
$\mathbf{1 1}$ & 0.583 & 0.011 & $\mathbf{3 1}$ & 0.652 & 0.004 \\
$\mathbf{1 2}$ & 0.567 & 0.014 & $\mathbf{3 2}$ & 0.564 & 0.014 \\
$\mathbf{1 3}$ & 0.725 & 0.001 & $\mathbf{3 3}$ & 0.564 & 0.014 \\
$\mathbf{1 4}$ & 0.810 & 0.000 & $\mathbf{3 4}$ & 0.477 & 0.036 \\
$\mathbf{1 5}$ & 0.560 & 0.015 & $\mathbf{3 5}$ & 0.477 & 0.036 \\
$\mathbf{1 6}$ & 0.583 & 0.011 & $\mathbf{3 6}$ & 0.648 & 0.004 \\
$\mathbf{1 7}$ & 0.583 & 0.011 & $\mathbf{3 7}$ & 0.657 & 0.004 \\
$\mathbf{1 8}$ & 0.599 & 0.009 & $\mathbf{3 8}$ & 0.730 & 0.001 \\
$\mathbf{1 9}$ & 0.466 & 0.040 & $\mathbf{3 9}$ & 0.576 & 0.012 \\
$\mathbf{2 0}$ & 0.603 & 0.009 & $\mathbf{4 0}$ & 0.477 & 0.036 \\
\hline & & & & & \\
\hline
\end{tabular}

According to table (2), the coefficient correlation of each item is significant at (0.01) and (0.05). It can be concluded that the test is highly consistent and valid to be used as a tool of the study.

\subsubsection{Reliability of the Test}

The test is regarded reliable when it gives the same results in case of re-applying it for the same purpose in the same conditions (Al-Agha, 1996:120). After applying the test on the pilot study, the researcher used Kuder-Richardson (K_R20) and Spearman Brown (Spilt-half) methods to measure the test reliability as it is presented in Table (3). (K_R20) depends on calculating the percentage of correct answers of the test items, and also on the variance of every item.

Table (3). (K_R20) coefficient and Split-half of the test

\begin{tabular}{lllll}
\hline (K_R20) coefficient & \multicolumn{3}{c}{ Split -half } \\
\hline \multirow{2}{*}{ Domain } & No. of & \multirow{2}{*}{ (K_R20) } & Correlation & Spearman \\
& items & between forms & Brown \\
Total & 40 & 0.956 & 0.925 & 0.961 \\
\hline
\end{tabular}

According to Table (3), the test proved to be highly reliable and could be used confidently in the basic experiment. (K_20) coefficient was (0.956) and the Spilthalf coefficient was (0.961) and they are good coefficients which could be depended on in applying the achievement test. 


\subsubsection{Scoring of the Test}

The test was scored by a simple traditional way. Each correct answer was awarded one point. The maximum average was (40) and the minimum was (zero). So, the total points for the whole test were 40 .

\subsubsection{Difficulty Coefficient}

Difficulty coefficient is measured by finding out the percentage of the wrong answers of each item made by the students ( Abu Nahia ,1994 :308). Having applied the formula, the difficulty coefficient of the test items varied between $(0.466-0.730)$ with a total mean $(0.58)$. Since the accepted items of the achievement test vary between (0.35-0.65), all the items are accepted and the test is suitable to be used as a tool of the study.

\subsubsection{Discrimination Coefficient}

The discrimination coefficient was calculated according to the following formula:

Table (4). Difficulty and Discrimination of Items of the Test

\begin{tabular}{|c|c|c|}
\hline No. & Difficulty coefficient & Discrimination coefficient \\
\hline 1 & 0.60 & 0.60 \\
\hline 2 & 0.533 & 0.60 \\
\hline 3 & 0.60 & 0.40 \\
\hline 4 & 0.60 & 0.80 \\
\hline 5 & 0.466 & 0.60 \\
\hline 6 & 0.466 & 0.80 \\
\hline 7 & 0.533 & 0.40 \\
\hline 8 & 0.466 & 0.80 \\
\hline 9 & 0.466 & 0.60 \\
\hline 10 & 0.533 & 0.80 \\
\hline 11 & 0.60 & 0.80 \\
\hline 12 & 0.466 & 0.80 \\
\hline 13 & 0.666 & 0.80 \\
\hline 14 & 0.466 & 1.00 \\
\hline 15 & 0.60 & 0.60 \\
\hline 16 & 0.60 & 0.60 \\
\hline 17 & 0.60 & 0.80 \\
\hline 18 & 0.533 & 0.80 \\
\hline 19 & 0.60 & 0.60 \\
\hline 20 & 0.666 & 0.60 \\
\hline 21 & 0.666 & 0.60 \\
\hline 22 & 0.666 & 0.60 \\
\hline 23 & 0.73 & 0.60 \\
\hline 24 & 0.666 & 0.40 \\
\hline 25 & 0.60 & 0.80 \\
\hline 26 & 0.60 & 0.60 \\
\hline 27 & 0.60 & 0.40 \\
\hline 28 & 0.666 & 0.80 \\
\hline 29 & 0.60 & 0.80 \\
\hline 30 & 0.60 & 0.60 \\
\hline 31 & 0.666 & 0.80 \\
\hline 32 & 0.533 & 0.60 \\
\hline 33 & 0.533 & 0.80 \\
\hline 34 & 0.60 & 0.60 \\
\hline 35 & 0.60 & 0.40 \\
\hline 36 & 0.466 & 0.80 \\
\hline 37 & 0.533 & 0.80 \\
\hline 38 & 0.73 & 0.80 \\
\hline 39 & 0.533 & 0.60 \\
\hline 40 & 0.60 & 0.60 \\
\hline TOTAL & 0.582 & 0.67 \\
\hline
\end{tabular}

The discrimination coefficient of the test items varied between (0.40-1.00) with a total mean (0.67). And since the accepted achievement test items should have discrimination coefficients larger than (0.25), all the items were accepted.

The discrimination coefficient of the test varied between (0.40-1.00) with a total mean (0.67). And since the accepted achievement test items should have discrimination coefficients larger than $(0.25)$, all the items were accepted.

\subsection{The Blended Program}

After reviewing the literature of education technology and scientific studies of developing and designing educational program models according to design criteria, the researcher decided to follow Al Jazar model to design the proposed educational program which aims at developing tenth graders' writing skills to the extent their competencies allow.

\subsubsection{Content of the Program}

The content of this suggested program was carefully selected to help improve the students writing skills through the blended learning program. The suggested program consisted of five units, based on the content of grade ten textbook. The program covered ten lessons. Each lesson was forty-five minutes.

\subsubsection{The Validity of the Program}

To test the program validity, the researcher submitted its first version to a group of supervisors and teachers of education technology. The researcher did the required adjustment according to their recommendations. Then the researcher prepared a list of criteria with (10) domains including (70) indicators which were given to a panel of specialists in education technology from the Islamic University, Al-Aqsa University, Al-Quds Open University, and Ministry of Education. The criteria were modified according to their recommendations into (9) domains with (69) indicators. Then the program package including (the software program - student's textbook - teacher's guide electronic test) was presented to the panel again to evaluate it according to the criteria list.

The researcher modified the program according to their suggestions and produced the final copy to be implemented to achieve the planned objectives.

\subsubsection{Pilot Experimenting of the Program}

To be sure of the program's suitability, it was experimented on a pilot study of the tenth grade in the same school other than the study sample so that the teacher who would apply it acquire the application experience, identifying difficulties of implementation, determining the time schedule for the basic experiment application and modifying what is necessary in the initial draft before implementing it on the basic study sample.

\subsubsection{Implementing the Program}

After examining the program's validity, and adjusting it for implementation, permission was issued from the Ministry of Education to implement the experiment on the 
study sample. The experiment lasted for ten weeks with one lesson a week.

\section{Results: Data Analysis}

The study aimed at investigating the effectiveness of a blended learning program on developing Palestinian tenth graders' English writing skills. The researchers used different statistical forms using the statistical program (SPSS) to analysis the collected data results. Tables were also used to clarify and present these data with analysis and interpretation.

Question One:

Are there differences in the achievement level in writing skills in the post test between the students of the experimental group (blended learning) and their counterparts of the control group?

To answer this question, the researchers tested the following null hypothesis:

There are statistically no significant differences at $(\alpha$ $\leq 0.05$ ) in the achievement level in writing skills in the post test between the students of the experimental group (blended learning) and their counterparts of the control group.

To examine this hypothesis, means and standard deviation of both groups' results on the post-test were computed. Independent Samples T-test was used to measure the significant differences. Table (5) describes this:

Table (5). T Test Independent Sample Results of Differences between the Experimental and the Control Group in the Post Test

\begin{tabular}{lllllll}
\hline sample & N & Mean & $\begin{array}{l}\text { Std. } \\
\text { Deviation }\end{array}$ & T. & $\begin{array}{l}\text { Sig. (2 } \\
\text { tailed) }\end{array}$ & $\begin{array}{l}\text { Sig. } \\
\text { level }\end{array}$ \\
\hline $\begin{array}{l}\text { Experim } \\
\text { ental }\end{array}$ & 20 & 29.90 & 4.399 & 3.81 & .000 & $\begin{array}{l}\text { Sig. at } \\
\text { Control }\end{array}$ \\
20 & 23.60 & 5.924 & 8 & & 0.01 \\
\hline
\end{tabular}

"t" table value at ( 38) df. At (0.05) Sig. level equal 1.686

"t" table value at (38) df. At (0.01) Sig. level equal 2.429

As shown in table (20) shows that the T. computed value is larger than $\mathrm{T}$. table in the test which means that there are significant differences at (á $\leq 0.01)$ in the total average score of the post-test between the experimental and control group in favor of the experimental group. The mean of the post-test in the experimental group reached (29.9), whereas the mean of the control group was (23.60). This result indicates that using the blended program is more effective than the traditional method in developing students' writing skills.

To measure the effect size of the blended the researchers computed " $\eta$ " using the following formula :( Affana, 2000: 42)

$$
\eta^{2} \quad=\frac{t^{2}}{t^{2}+d f}
$$

Table (6). The Table References to Determine the Level of Size Effect $\left({ }^{2} \boldsymbol{\eta}\right)$

\begin{tabular}{llll}
\hline \multirow{2}{*}{ Test } & \multicolumn{3}{l}{ Effect size criterion } \\
& Small & Medium & Large \\
\hline${ }^{2} \eta$ & 0.01 & 0.6 & 0.14 \\
\hline
\end{tabular}

Table (7). The Effect Size of the program on the Experimental and the Control Groups Achievement in the Post-Test

\begin{tabular}{lllll}
\hline Test & df & $\mathbf{T}$ & ${ }^{2} \boldsymbol{\eta}$ & Effect size \\
\hline $\begin{array}{l}\text { Post test } \\
\text { (total) }\end{array}$ & 38 & 3.818 & 0.277 & Large \\
\hline
\end{tabular}

Table (7) shows that the effect size of the program is large on students' achievement in writing skills. This means that the effect is significant. This large effect may be due to the activities and techniques which are used in the blended program to develop students' writing skills.

Question Two:

Are there differences in the achievement level in writing skills between the students of the experimental group (blended learning) in the pre-post test?

To answer this question, the researchers tested the following null hypothesis:

There are statistically no significant differences at $(\alpha$ $\leq 0.05$ ) in the achievement level in writing skills between the students of the experimental group (blended learning) and in the pre-post test.

Table (8). T. Test Paired Sample Results of the Differences in the Total Average Score between the Pre-Test and the Post Test of the Experimental Group

\begin{tabular}{lllllll}
\hline sample & N & Mean & $\begin{array}{l}\text { Std. } \\
\text { Deviation }\end{array}$ & T. & $\begin{array}{l}\text { Sig. (2 } \\
\text { tailed) }\end{array}$ & $\begin{array}{l}\text { Sig. } \\
\text { level }\end{array}$ \\
\hline Post & 20 & 29.90 & 4.399 & 11.3 & .000 & $\begin{array}{l}\text { Sig. at } \\
0.01\end{array}$ \\
Pre & 20 & 13.35 & 5.869 & 57 & & \\
\hline
\end{tabular}

"t" table value at ( 19) df. At (0.05) Sig. level equal 1.729

"t" table value at ( 19) df. At (0.01) Sig. level equal 2.539

As shown in table (8) shows that the T. computed value is larger than T. table in the test which means that there are significant differences at $(a ́ \leq 0.01)$ in the total average score of the experimental group in favor of the post application. The mean of the post-test group reached (29.90), whereas the mean of pre-test was (13.35). This means that there are statistically significant differences between the pre and post application of the experimental group in favor of the post application. This means that using the blended program is very effective in the achievement of tenth graders' writing.

Table(9). The Effect Size of blended program in the Pre- and the Post Test of the Experimental Group

\begin{tabular}{lllll}
\hline Test & df & T & ${ }^{\mathbf{2}} \boldsymbol{\text { Effect size }}$ \\
\hline total & 19 & 11.357 & 0.871 & Large \\
\hline
\end{tabular}

Table (9) shows that the effect size of program is large on students' achievement in writing. This means that the effect is significant. 


\section{Discussion}

The study aimed at investigating the effectiveness of a blended learning program on developing Palestinian tenth graders' English writing skills.

To achieve this aim, the researchers adopted the experimental approach where there were two similar groups: the experimental and the control groups. The population of the study was all the tenth graders in Rafah Directorate of Education. The sample of the study, namely (40) students were selected randomly from Shohada' Rafah Basic School. Each group has twenty students. Both were proved to be similar in terms of age, general achievement, general achievement in English and English writing skills achievement. The researcher used three instrument and tools to collect data: content analysis, a pre-post test, and the blended learning program. The experiment started at the second semester of the school year (2012-2013) and lasted for eight weeks. The researchers used a variety of blended techniques and activities. The population of the study consisted of all tenth graders at the governmental schools in Rafah Directorate.

\section{Findings}

1. In the light of the statistical results, the researchers concluded the following findings:

2. There are differences of statistical significance in the tenth graders' achievement level of English writing skills due to the teaching learning method i.e. the blended learning program.

3. There are differences of statistical significance in the tenth graders' achievement level of English writing skills for the experimental group in favor of the post application.

\section{This May be Attributed to}

1. Employing more than one sense as well as addressing the students' different learning styles through variety of the activities, techniques and multi-media which included pictures, texts, videos, and PowerPoint slides.

2. The blended program created on-going interactive and a non-threatening learning environment that encouraged interactions between students and teachers, enhanced communication, cooperation and teamwork and encouraged active participation which increased their motivation and interest in learning.

3. The program also offered continuous feedback which reflected in students' progress in learning if the answers were right or modifying them if they were wrong.

4. The program helped students develop self-learning strategies in an interesting way, recognize the relations between the content components, re-organize the information presented in various forms, and give deductions from the available information such as searching for additional information about the writing skill from the searching drives on the internet.
5. The program also enabled students to express themselves freely via writing and to participate according to their competencies and learning styles.

6. Discussing issues on e-mail and Facebook walls was effective in developing students' writing skills.

7. This program developed students' communication skills, their interaction with the educational materials presented, co-operation among students, self-evaluation tools, informational search and training opportunities which are not found in the traditional method.

\section{Conclusion}

Based on the findings, derived from the results of this study, the following conclusions were reached:

1. Blended learning provided students with a better learning environment through variety of multi-media resources which enhanced self-learning strategies and reflected on their achievement of English language.

2. Blended learning stimulated students towards independent practice of English language instead of direct instruction.

3. Blended learning was very effective in motivating shy students and low achievers towards participation and interaction both in synchronous and asynchronous activities because they were not criticized.

4. The blend provided students with enjoyment, pleasure, enthusiasm and variation which were significant enough to affect the students' achievement positively.

5. Self-evaluation tasks with immediate feedback gave students a chance for confidence and self-evaluation to support self- learning strategies.

6. Availability of on-line and off-line resources enabled students to revisit the language at the ease and comfort of time.

\section{Pedagogical Implications}

In the light of the study results, the researchers suggest the following:

1. Teachers should be aware of their students' needs and abilities and choose the suitable blend for them.

2. Teachers should train their students on self-learning strategies to enhance blended learning potentials.

3. Teachers should not be hunting for mistakes. In fact, mistakes are source of learning.

4. Teachers should avoid teacher-centered class and move towards student-centered classes.

5. Classroom motivating environment could be created through utilizing all the available resources inside and outside the walls.

6. Students like to write and talk about things related to their real life and experiences. So teachers should always create reasons for learning.

7. Training teachers on strategies, types and implementation of blended learning is a pre-requisite 
for establishing blend strategy inside schools.

\section{Recommendations}

In the light of the results, the researchers recommend:

Curriculum designers and decision makers should enrich the Palestinian curriculum with different educational activities that enhance blended learning and practicing English language and supply schools with the necessary equipment for employing blended learning such as enough computer labs, interactive smart boards, multi-media resources and Internet access.

Supervisors are recommended to provide teachers with instructional materials which increase their awareness of blended learning as a new method that suits modern trends in teaching and learning and conduct workshops to enhance teachers' competencies of implementing blended learning.

English language teachers are recommended to change the methods and approaches of teaching from traditional to the blend which is based on the students' real involvement, help students use English language in "life-like" situations such as emails, chatting, forums, text messaging and blogs and change their role from instructors who dominate the class into educators whose role is to facilitate, guide, coordinate and support students to communicate.

\section{Recommendations for Further Studies}

The researchers suggested the following recommendations for further studies:

1. Comparing and contrasting teachers' perspectives regarding blended learning.

2. Investigating the impact of blended learning on developing students' reading for comprehension in English language.

3. Parents' role in motivating their children in utilizing technology in self-learning.

4. The effectiveness of blended learning on in-service teachers training and their attitudes towards it should be researched.

5. Investigating English language majors' attitude towards utilizing the Moodle in teaching inside the Islamic University.

6. The efficiency of governmental schools in implementing blended learning program.

\section{References}

[1] Abo- Mosa, M. A. and Al-Soos S. A. (2010). The impact of a training program based on blended learning on teachers' competence in designing and producing educational multi-media. Research presented to the first international conference of Omani Association for Educational Technologies. Massqat: Oman.

[2] Abu Nahia, S. (1994). Educational Measurement. $1^{\text {st }}$ ed.,
Cairo: Anglo Egyptian Library.

[3] Al Agha, I. (1997). Educational Research, Elements, Methodology and Tools. The Internal Consistency Validity ( $4^{\text {th }}$ ed.). Gaza, Palestine: Islamic University.

[4] Affana, a. (2000). The effect size in educational research. Palestinian Educational Studies Journal 3(6).

[5] Al Fiky, A. I. (2011). Blended Learning: Educational Design, Multi-media, Creative Thinking. Amman (Jordan): Dar Athaqafa for publishing and distribution.

[6] Al-Haq A., F. \& Al-Sobh A., M. (2010). The effect of a web-based writing instructional EFL program on enhancing the performance of Jordanian secondary students. The JALT CALL Journal 6(3) : 189-218.

[7] Al-Jarf, R. (2004). The Effect of Web-based Learning on Struggling EFL College Writers. Foreign Language Annals 37(1): 49-57. Retrieved February $6^{\text {th }}, 2013$ from:http://www.eric.ed.gov/ERICWebPortal/search/detailm ini.jsp? nfpb=true\&_\&ERICExtSearch_SearchValue 0=EJ $683959 \&$ ERICExtSearch_SearchType_ $\overline{0}=$ no\&accno=EJ683 959

[8] Al-Jazar, A. A. (2002). The Effectiveness of Using Multi-media Computer Aided Teaching in Acquiring Some Scientific Concepts Levels According to "Febrayer" Model to evaluate these concepts. Education Journal, Al-Azhar University (125).

[9] Al-Masry, N. M. S. (2012). The Effectiveness of Using Blended Learning in Teaching A unit in English language in Second Secondary Class in Mecca. Unpublished Master Degree, Faculty of Education, Mecca, Om El-Qura University.

[10] Angelillo, J. (2002)." A Fresh Approach to Teaching Punctuation: Helping Young Writers Use Conventions With Precision", New York: Scholastic, Inc.

[11] Bates, A.W. (2000). Managing Technological Change: Strategies for College and University Leaders. San Francisco: Jossey Bass.

[12] Bath, D. \& Bourke, J. (2010).Getting started with blended learning. Australia: Griffith Institute for Higher Education.

[13] Bersin \&Associates (2003). Blended Learning: what works? Retrieved March $21^{\text {st }}$ from http://www.bersin.com/Search/Index.aspx?search=blended $\% 20$ learning\&idx $=$ research

[14] Billigmeier, G.M. (2011). Blended Learning: Design and Implementation. Retrieved March $26^{\text {th }}, 2013$ from http://imet.csus.edu/imet10/portfolio/billigmeier_g/billigmei er/ROLFinal.pdf

[15] Bonk, C. J., Graham, C. R. (2006). The handbook of blended learning: Global perspectives, local designs. San Francisco: Pfieffer.

[16] Carroll. R. T. 1990. "Students Success Guide: Writing Skills." Retrieved March 30 $0^{\text {th }}, 2013$ from www.skepdic.com/refuge/writing skills.pdf.

[17] Chastain, K. (1988). Developing Second Language Skills: Theory and Practice. San Diego: Harcourt Brace Jovanovich.

[18] DeLacey, B.J., \& D.A. Leonard (2002). Case study on technology and distance in education at the Harvard Business 
School. Educational Technology and Society, 5(2): 13-28

[19] Dixon (1986). Teaching Composition to Large Classes. English Teaching Forum, 25(3): 22-43.

[20] Driscoll, M. (2002). Blended learning: Let's get beyond the hype. Learning and training innovations news line. Retrieved March 22 2013 from http://www.ltimagazine.com/ltimagazine/article/articleDetail .jsp?id=11755.

[21] Dziuban, C. D., Hartman, J. L. \& Moskal, P. D. (2004). Blended Learning. Retrieved March $2^{\text {nd }}, 2013$ from Educause $\mathrm{http}: / /$ www.educause.edu/library/resources/blended-learning

[22] Finn, A. \& Bucceri, M. (2004). A case study approach to blended learning. Los Angeles: Centra Software. Retrieved March $\quad 3^{\text {rd }}$, 2013 from http://www.conferzone.com/resource/wp/CaseStudy_Blende dLearning.pdf.

[23] Gamble, Valerie J. (2005). The effectiveness of blended learning for the employee. Dissertation Unpublished. Fielding Graduate University.

[24] Garrison, R., \& Vaughan, H. (2008). Blended learning in higher education: Framework, principles and guidelines. San Francisco: Jossey-Bass.

[25] Gebhardt, R. C. \& Rodrigues, D. (1989). Writing processes and Intentions. America: D. C. Health and company.

[26] Gould, T. (2003). Hybrid classes: Maximizing institutional resources and student learning. Proceedings of the 2003 ASCUE Conference, Myrtle Beach, South Carolina. Retrieved March $\quad 8^{\text {th }}$, 2013 fromhttp://www.ascue.org/files/proceedings/2003/p54.pdf.

[27] Graham, C. R., \& Robinson, R. (2007). Realizing the transformational potential of blended learning. In Blended Learning Research Perspectives (83-110). Needham, MA: The Sloan Consortium.

[28] Graham, C.R. (2004). Blended learning systems: Definition, current trends, and future directions. In The handbook of blended learning: Global perspectives, local designs, ed. C.J.Bonk and C.R. Graham, 3-21. San Francisco: Pfeiffer. Retrieved March 23 $3^{\text {rd }}, \quad 2013$ from http://www.academia.edu/563281/Blended_learning_system s_Definition_current trends and future directions

[29] Halliday, M., \& Hasan, R. (1985). Language, context, and text: Aspects of language in a social semiotic perspective. Deakin: Deakin University.

[30] Haring L. W. (1994).Personalizing Education, New York, Hudelson, S.: Write on children writing in ESL, center for applied linguistics, USA, New Jersey, Prentice Hall Regents.

[31] Harmer, J. (2001). "How to Teach English." An Introduction to the Practice of English Language Teaching. Essex, England: Pearson Education Limited.

[32] Hofmann J. (2011). Top 10 Challenges of Blended Learning. Retrieved March 23 ${ }^{\text {rd }}$, 2013 from http://www.trainingmag.com/article/soapbox-top-10-challen ges-blended-learning

[33] Hooper, S. (1992). Cooperation learning and computer-based instruction. Educational Technology Research and
Development, 40(3): 21-38.Retrieved April 6 ${ }^{\text {th }}, 2013$ from http://link.springer.com/journal/11423

[34] Huang, R. H., Zhou, Y. L., \& Wang, Y. (2006). Blended Learning: Theory into Practice. Beijing: Higher Education Press.

[35] Johnstone, K.M. et. al (2002). Effects of Repeated Practice and Contextual-Writing Experiences on College Pupils' Writing Skills. Journal of educational psychology, 94(2): 305-313.

[36] Jolliffe, A., Ritter, J., \& Stevens, D. (2001). The Online Learning Handbook Developing and Using Web-Based Learning. London: Kogan Page.

[37] Joy-Matthews, J., Megginson, D., \& Surtees, M. (2004). Human resource development (3rd ed.). London: Kogan Page.

[38] Kaoud, A. A. E. (2007). The Effectiveness of Internet Blended Discussion Group on Developing Some Composition Writing Skills of First Year Secondary School Students. Retrieved April $3^{\text {rd }}, 2013$ from http://srv3.eulc.edu.eg/eulc_v5/libraries/start.aspx.

[39] Kendall, M. (2001). Teaching online to campus-based students: The experience of using WebCT for the community information module at Manchester Metropolitan University. Education for Information, 19(4): 325-346.

[40] Kerres, M., \& De Witt, C. (2003). A didactical framework for the design of blended learning arrangements. Journal of Educational Media, 28(2/3): 101-113.

[41] King, G. (2003)." Good Writing Guide". Updated ed., Glasgow: Harper Collins Publishers.

[42] Kocoglu, Z., Ozek, Y. and Kesli, Y. (2011). Blended learning: Investigating its potential in an English language teacher training program. Australasian Journal of Educational Technology, 27(7): 1124-1134.

[43] Lindsay, C. \& Knight, P. (2006). Learning and Teaching English. A Course for Teachers, Oxford University Press

[44] Min, W. \& Li, J. Z. (2007). Implicit Part of Process Writing in Academic English Writing. US-China Foreign Language $5(8)$.

[45] NACOL. (2008). Fast facts about online learning (Issue report,1-6). Vienna: North American Council for Online Learning. Retrieved March $5^{\text {th }}$, 2013, from http:// www.NACOL.org

[46] Norman, R.; Singer, D.; McPherson, C. and Bradburn, K. (2005). Project-oriented Technical Writing, $5^{\text {th }}$ Edition. Huntsville: University of Alabama.

[47] Oblender, Th. (2002). A hybrid Course Model: One Solution to the High Online dropout Rate. Learning with Technology, 29(6): 42-46.

[48] Olshtain, E. (2001). Functional tasks for mastering the mechanics of writing and going just beyond. In $\mathrm{M}$. Celce-Murcia (Ed.), Teaching English as a second or foreign language (3rd ed., 207-217). United Sates: Heinle \& Heinle.

[49] Osguthorpe, R. T. and Graham, C. R., (2003). Blended learning environments: Definitions and directions. The Quarterly Review of Distance Education, 4( 3): 227-233. 
[50] Palmer, D. (1986). Writing Skills, at the chalk face; Practical Techniques in Language Teaching. London: Edward Arnold Publishers Ltd.

[51] Richards, J. (1990). The language teaching matrix. England: Cambridge University press.

[52] Richards, J. C.( 2003). Second Language Writing. Ken Hyland: Cambridge Language Education.

[53] Richards, J.C., \& Renandya, W.A. (Eds.). (2005).Methodology in language teaching: An anthology of current practice $\left(5^{\text {th }}\right.$ ed.). Cambridge: Cambridge University Press.

[54] Rossett, A., Douglis, F., \& Frazee, R. V. (2003). Strategies for building blended learning. Learning Circuits. Retrieved April $27^{\text {th }}$, 2013 from http://www.learningcircuits.org/2003/jul2003/rossett.htm.

[55] Rovai, A., \& Jordan, H. (2004). Blended learning and sense of community: A comparative analysis with traditional and fully online graduate courses. The International Review of Research in Open and Distance Learning, 5 (2). Retrieved April $\quad 3^{\text {rd }}$, 2013 from: http://www.irrodl.org/index.php/irrodl/article/view/192/274.

[56] Saade, R.G. and Kira, D. (2009). Computer anxiety ine-learning: The effect of computer self-efficacy. Journal of Information Technology Education (8): 177-190.

[57] Saunders, G., \& Klemming, F. (2003). Integrating technology into a traditional learning environment. Active Learning in Higher Education, 4(1): 74-86.
[58] Sayed, E.. A. A. (2012). The Effect of Using Electronic Portfolios on Developing the English Language Writing Skills for Second Grade Preparatory School Students. Retrieved April $\quad 3^{\text {rd }}, \quad 2013$ from http://srv3.eulc.edu.eg/eulc_v5/libraries/start.aspx.

[59] Sharma, Pete \& Barrett, Barney (2007). Blended Learning: Using technology in and beyond the language classroom. London: Macmillan Publishers Limited.

[60] Shih, R. (2011). Can Web 2.0 technology assist college students in learning English writing? Integrating Face book and peer assessment with blended learning. Australasian Journal of Educational Technology, 27(5): 829-845.

[61] Sokolik, M. (2003). Writing. Practical English Language Teaching. Edited by D Nunan. New York: McGraw-Hill, $87-108$.

[62] Sun, T. (2003) Read Me First! A Style Guide for the Computer Industry, Chapter One. Second Edition., New Jersey: Prentice Hall.

[63] Tang, X. (2006). Principles in Teaching Process. Writing in a Learner-Centered Classroo, 3 (2), (Serial No.26) East China Jiao Tong University.

[64] Wenger, E. (1999). Communities of Practice: Learning, Meaning and Identity. New York: Cambridge University Press. 